\title{
Bağımsız Denetçinin Eğitim Seviyesi ve Mesleki Tecrübesine Göre Mesleki Bağlılık ve Denetimde Kalite Algı Düzeyi ${ }^{1}$
}

\author{
Zeynep HATUNOĞLU
}

Prof. Dr., Tarsus Üniversitesi,

Uygulamalı Bilimler Fakültesi, Gümrük İşletme Bölümü zhatunoglu@hotmail.com

Orcid ID: https://orcid.org/0000-0002-9103-2766

\section{Nurettin KOCA}

Öğr. Gör. Dr., Kahramanmaraş Sütçü İmam Üniversitesi, Afşin Meslek Yüksekokulu, Muhasebe ve Vergi Bölümü kocanurettin417@gmail.com

Orcid ID: https://orcid.org/0000-0002-3309-9428

\section{$\ddot{O} \mathbf{z}$}

Bağımsız denetimde kalite, gerçeğe ve ihtiyaca uygun karşılaştırılabilir finansal bilgilerin kullanıcılara iletilmesi şeklinde ifade edilmektedir. Bağımsız denetçinin mesleki bağlılığı, literatürde denetimde kaliteyi etkileyen faktörlerden biri olarak kabul edilmektedir. Bu çalışma, bağımsız denetçinin mesleki bağlılık ve denetimde kalite alg1 düzeyinin denetçinin eğitim seviyesi ve mesleki tecrübesine göre farklılık oluşturup oluşturmadığının tespit edilmesi amacıyla yapılmıştır. Araştırma, aktif denetim çalışmalarını yürüten bağımsız denetçilere anket yapılması suretiyle gerçekleştirilmiştir. Anket 355 denetçiye uygulanmıştır. Verilerin analizinde SPSS 24.0 programından yararlanılmıştır. Yapılan analiz sonucunda, bağımsız denetçinin mesleki bağlılık ve denetimde kalite alg1 düzeyinin denetçinin eğitim seviyesi ve mesleki tecrübesine göre anlamlı bir farkl1lık oluşturduğu görülmüştür.

Anahtar Kelimeler: Bağımsız Denetçi, Mesleki Bağlılık, Bağımsız Denetimde Kalite.

\footnotetext{
${ }^{1}$ Makale Geliş/Kabul Tarihi: 11.05.2020 / 08.10.2020

Künye Bilgisi: Hatunoğlu, Z. ve Koca, N. (2020). Bağımsız Denetçinin Eğitim Seviyesi ve Mesleki Tecrübesine Göre Mesleki Bağlllık ve Denetimde Kalite Algl Düzeyi. Kahramanmaraş Sütçü İmam Üniversitesi Sosyal Bilimler Dergisi, 17 (2), 1118-1134. DOI: $10.33437 / k s u s b d .735605$
} 


\title{
Occupational Commitment and The Audit Quality Perception Level Based on Educational Level and Occupational Experience of Independent Auditor
}

\begin{abstract}
Independent audit quality is expressed as the transmission of comparable financial information to the users. Occupational commitment of the independent auditor is considered as one of the factors affecting the quality of the audit in the literature. This study was carried out in order to determine whether the independent auditor's occupational commitment and quality perception in the audit differed from the auditor's level of education and occupational experience. The research was carried out by conducting a survey to independent auditors who are active in audit activities. The survey was administered to 355 auditors. SPSS 24.0 program was used in the analysis of the data. In the result of the analysis, it was seen that the independent auditor's occupational commitment and quality perception in the audit made a significant difference according to the auditor's education level and occupational experience.
\end{abstract}

Keywords: Independent Auditor, Occupational Commitment, Quality in Independent Audit.

\section{GİRİŞ}

Finansal tabloların, işletme ile ilgilenen çıkar gruplarına işletmenin faaliyet sonuçları hakkında faydalı bilgiler vermesi beklenmektedir. Faydalı finansal bilginin, ihtiyaca uygun, gerçeğe uygun, karşılaştırılabilir, doğrulanabilir, anlaşılabilir ve zamanlı olması beklenmektedir (TFRS, Kavramsal Çerçeve, Bölüm 3). Ancak finansal tablolardaki bilgiler her zaman gerçeği yansıtmayabilir. Gerçeğe uygun şekilde sunulmayan bilgiler finansal piyasaları olumsuz etkilemektedir. Ekonomide bu tür olumsuzlukların yaşanmaması için, finansal tabloların bağımsız denetim kuruluşları tarafından denetlenmesine ihtiyaç duyulmaktadır. Bağımsız denetim, bilgiyi sunanlar ile kullananlar arasındaki bilgi akışının kalite güvencesini oluşturmaktadır.

Bağımsız denetim; denetime tabi olan işletmelerin belirli bir döneme ait finansal tablolarında sundukları bilgilerinin muhasebe ve finansal raporlama standartlarına uygunluğu ve doğruluğu hakkında makul bir güvence vermek amacıyla, tarafsızca bağımsız denetim standartlarına uygun bir şekilde geçerli ve 
güvenilir kanıt toplanması, değerlendirilmesi ve oluşturulan görüşün bir rapor halinde ilgililere iletilmesi sürecidir (Koca, 2019: 1). Bir diğer şekilde ifade edecek olursak, bağımsız denetim; işletme sahipleri, yöneticiler ve azınlık pay sahipleri arasında çıkabilecek anlaşmazlıkları önleme görevini üstlenen, piyasada güven ortamının oluşması için gerekli olan bir hizmet türüdür (DeAngelo, 1981: 185). Bu hizmet türünde denetim süreci, finansal tablolarda yer alan rakamların, işletmenin faaliyet sonuçlarını ve mali durumunu gerçeğe en yakın bir biçimde yansıtıp yansıtmadığının belirlenmesine ilişkin işlemlerden oluşmaktadır (AlThuneibat vd., 2011: 317).

Kıt ekonomik kaynakların etkin, verimli bir şekilde kullanılması ve adaletli bir şekilde dağıtılabilmesi için bağımsız denetim faaliyetinin kaliteli bir şekilde yürütülmesi gerekir. Bağımsız denetim kalitesi, denetim firması tarafından müşteri işletmenin finansal tablolarına ait bilgilerin yasal düzenlemelere göre hazırlanıp hazırlanmadığının tespit edilmesi ve bu doğrultuda bilgi kullanıcılarına makul bir güvence vermesi bakımından da son derece önemlidir (Akçay ve Bilen, 2019: 26). Bağımsız denetim kalitesi; mali tabloların önemli hata ve yanlışlıklar barındırmadığına dair güvencenin verilmesi (Yaşar, 2013: 467; Erdoğan ve Azgın, 2018: 50) olarak tanımlanmaktadır.

Denetim kalitesini etkileyen birçok faktör bulunmaktadır. Bu faktörler, denetim firması ve denetlenen işletme ile ilgili faktörler ve standartlar olarak sıralanabilir. $\mathrm{Bu}$ faktörlerden en önemlisi, denetimde kaliteyi doğrudan etkilemesi nedeniyle, denetim firmasında görevli olup denetlenen işletme ile irtibatlı olan ve denetimi standartlara göre yürüten bağımsız denetçidir. Bağımsız denetçinin yüksek mesleki bağlılık düzeyine sahip olması ve tarafsız davranabilmesi denetimde kalitenin sağlanabilmesi için önemlidir.

Mesleki bağl1lık, mesleki kimliği ön plana çıkarmak, mesleğinin gerekleri hususunda titiz davranmak, işine sadakat duymak, mesleki faaliyetlerini yerine getirirken mesleki hedef, değer, norm ve etik ilkelere uygun hareket edilmesi (Tak ve Çiftçioğlu, 2008; Özdevecioğlu ve Aktaş, 2007; Özmen vd., 2005; Bakan 2011: 14) olarak tanımlanabilir. Mesleki bağl1lık, duygusal bağlılık, devam bağl1lığı ve normatif bağl1lık olmak üzere üç alt boyuttan oluşmaktadır. Duygusal bağl1lık, bir bireyin mesleğine olan duygusal bağlılı̆̆ını ve bireyin mesleğinde kalma isteğini ifade eder. Devam bağlılı̆̆ı, çalışanların fayda (mesleği sürdürme) ve maliyet (meslekten ayrılma) analizi yaparak bağlılık geliş̧irmesi olarak tanımlanır. Normatif bağl1lık ise, bir bireyin mesleğini sürdürmesi ile ilgili olarak sorumluluk ve zorunluluk hissetmesi şeklinde ifade edilir (Lee vd., 2000: 801; Blau, 2003: 470; Mills ve Fullagar, 2017: 38; Meyer vd., 1993; Tak ve Çiftçioğlu, 2009: 37; Çetin vd., 2010: 126). 
Literatürde bağımsız denetimde kaliteyi etkileyen faktörler ile ilgili birçok çalışma bulunmaktadır. Bu çalışmalarda denetim süresinin (Al-Thuneibat vd. 2011), denetim firması büyüklüğünün (Davidson ve Neu 1993), denetçinin cinsiyetinin (Mgbame vd. 2012), denetim tecrübesinin (Cahan vd. 2015), mesleki aidiyetin (Selimoğlu ve Yeşilçelebi 2014), denetim ortağının zorunlu rotasyonunun (Lennox vd. 2014), denetçinin bağımsızlı̆̆ının (Aslanoğlu ve Başkan 2016), kurumsal yönetim (Gör (2016) ve yaratıcı muhasebe uygulamalarının (Aslanoğlu vd. 2016) bağımsız denetimin kalitesine etkileri incelenmiştir. $\mathrm{Bu}$ çalışmada ise bağımsız denetçinin mesleki bağlılık ve denetimde kalite algı düzeyinin denetçinin eğitim seviyesi ve mesleki tecrübesine göre farklılık oluşturup oluşturmadığının tespit edilmesi amaçlanmıştır.

\section{ARAŞTIRMANIN YÖNTEMI}

Çalışmanın bu kısmı; araştırmanın amacı, araştırmanın evreni ve örneklemi, araştırmanın sınırlılıkları, araştırmada kullanılan veri toplama yöntemi ve araştırmanın hipotezleri alt başlıklarında oluşmaktadır.

\subsection{Araştırmanın Amacı}

Bağımsız denetçilerin mesleki standartlara ve yürürlükteki mevzuat hükümlerine uygun şekilde mesleklerini icra etmeleri beklenmektedir. Eğitim seviyesi ve mesleki tecrübe her meslekte olduğu gibi bağımsız denetçilik mesleğinde de büyük önem arz etmektedir. Bu çalışma, bağımsız denetçinin mesleki bağlılık ve denetimde kalite algı düzeyinin denetçinin eğitim seviyesi ve mesleki tecrübesine göre farklılık oluşturup oluşturmadığını tespit etmek amacıyla yapılmıştır.

\subsection{Araştırmanın Evreni ve Örneklemi}

Türkiye'de 02.11.2011 tarih 660 sayılı Kanun Hükmünde Kararname ile Kamu Gözetimi, Muhasebe ve Denetim Standartları Kurumu (KGK) oluşturulmuştur. Araştırmanın yapıldığı dönemde (2017 yılı) Kamu Gözetimi Muhasebe ve Denetim Standartları Kurumu tarafindan yetkilendirilmiş çalışmanın tarihi itibariyle 242 bağımsız denetim kuruluşu ve 15.303 bağımsız denetçi bulunmaktadır (www.kgk.gov.tr).

$\mathrm{Bu}$ denetçilerin büyük bir kısmı yetkilendirilmiş olan bağımsız denetim firmalarında aktif olarak çalışmaktadır. Bağımsız denetçinin mesleki bağlılık ve denetimde kalite algı düzeyinin denetçinin eğitim seviyesi ve mesleki tecrübesine göre farklılık oluşturup oluşturmadığını tespit etmek amacıyla yaptığımız anket çalışması KGK (Kamu Gözetim Kurumu) tarafindan yetkilendirilmiş bu denetçilere uygulanmıştır. 
Türkiye'de bulunan 242 denetim firmasının 199'u İstanbul, Ankara ve İzmir'de bulunmaktadır. Bu nedenle araştırmanın evrenini İstanbul, Ankara ve İzmir illerinde bulunan bağımsız denetim firmalarında aktif olarak çalışan yaklaşık olarak 3.000 bağımsız denetçi oluşturmaktadır. Araştırmada istatistiksel analizlerin güvenilirliği açışından 450 ankete ulaşılması hedeflenmiştir. Ancak 355 denetçiye anket uygulanabilmiştir. Yapılan anket uygulamasının örneklem sayısı açısından yeterli olup olmadığını tespit etmek için Nakip (2006: 236) tarafından belirtilen formül kullanılmıştır. Yapılan hesaplama sonucunda 341 örneklem büyüklüğünün yeterli olduğu görülmüştür.

Normallik (çok değişkenli) ve doğrusallık varsayımlarını güçleştiren uç değerlerin olup olmadığı Mahalanobis uzaklığına göre incelenmiştir. Mahalanobis uzaklığı, çok değişkenli aykırı değerlerin tespitinde kullanılan tekniktir (Esen ve Timor, 2019: 267). Anketler için veri analizini etkileyecek düzeyde uç değerler olmasından dolayı 355 olan veri setinden 11 anket çıkarılmış ve analizler 344 örneklem üzerinden yapılmıştır. Örneklemin illere göre dağglımında ise "tabakalı örnekleme" yöntemi kullanılmıştır. Toplam 344 anketin İstanbul, Ankara ve İzmir'de uygulanan sayıları aşağıda Tablo 1'de verilmiştir.

Tablo 1. Tabakalı Örnekleme Yöntemi İle Örnekleme Alınan Denetçi Sayıları

\begin{tabular}{ccccc}
\hline Tabaka No & İler & $\begin{array}{c}\text { Aktif } \\
\text { Çalışan } \\
\text { Denetçi } \\
\text { Sayısı }\end{array}$ & $\begin{array}{c}\text { Tabaka } \\
\text { Ăgırlığı }\end{array}$ & $\begin{array}{c}\text { Örnekleme } \\
\text { Alınan } \\
\text { Denetçi Sayısı }\end{array}$ \\
\hline $\mathbf{1}$ & İstanbul & 2250 & $2250 / 3000=0,75$ & $0,75 \times 344=258$ \\
\hline $\mathbf{2}$ & Ankara & 562 & $562 / 3000=0,19$ & $0,19 \times 344=65$ \\
\hline $\mathbf{3}$ & İzmir & 188 & $188 / 3000=0,06$ & $0,06 \times 344=21$ \\
\hline TOPLAM & & $\mathbf{3 0 0 0}$ & $\mathbf{1 . 0 0}$ & $\mathbf{3 4 4}$ \\
\hline
\end{tabular}

Tablo 1'de görüldüğü gibi yapılan tabakalı örneklem dağılımına göre örneklem alınan denetçi sayısı İstanbul'da 258 (\%75), Ankara'da 65 (\%19), İzmir'de $21(\% 6)^{\prime}$ dir.

\subsection{Araştırmanın Sınırılıkkları}

$\mathrm{Bu}$ çalışma, İstanbul, Ankara ve İzmir'de bulunan bağımsız denetim firmalarında görevli denetçiler ile sınırlı tutulmuştur. Katılımcıların anketi cevaplarken yanıltıcı bilgi verme olasılıkları da çalışmanın diğer bir kısıtıdır. Sosyal bilimler alanında yapılan çalışmaların genel sınırlıkları bu çalışma için de geçerlidir. 


\subsection{Araştırmada Kullanılan Veri Toplama Yöntemi}

Veriler, yüz yüze görüşme tekniği olan anket uygulanarak toplanmıştır. Anket İstanbul, İzmir ve Ankara' da bağımsız denetim firmalarından görevli denetçilere uygulanmıştır. Araştırma verilerinin sağlıklı bir şekilde elde edilebilmesi için işinde uzman anketörlerden profesyonel destek alınmıştır.

Anket üç bölümden oluşmaktadır. İlk bölümde, katılımcıların demografik özellikleriyle ilgili sorulara, ikinci bölümde mesleki bağlllık ile ilgili önermelere ve son bölümde ise denetimde kalite algısını ölçen önermelere yer verilmiştir. Anketin ikinci ve üçüncü bölümünde yer alan önermeler 5'li likert ölçeği (1= Kesinlikle Katılmıorum, 2=Katılmıorum, 3=Kararsızım, 4=Katılıyorum, 5=Kesinlikle Katılıyorum) ile ölçülmüştür. Araştırmanın amacı doğrultusunda hazırlanan ankette iki değişken kullanılmıştır. Bu değişkenler "mesleki bağlılık" ve "denetimde kalitedir". Mesleki bağl1lık (Duygusal, Devam ve Normatif Bağll1ık) değişkenine ait ölçek Meyer vd. (1993) tarafından geliştirilmiştir ve 18 önermeden oluşmaktadır. Denetimde kalite algısına ait önermeler literatür incelemesi sonucunda hazırlanmıştır. Denetçi ile denetim firması boyutunda 42 önerme bulunmaktadır.

Anket formunda yer alan değişkenlere ait güvenilirlik katsayıları aşağıda Tablo 2'de verilmiştir.

Tablo 2. Mesleki Bağl1lık ve Denetimde Kalite Algısı Düzeyi ve Alt Boyutlarının Güvenilirlik Katsayıları

\begin{tabular}{ccc}
\hline Düzeyler ve Boyutları & $\begin{array}{c}\text { İfade } \\
\text { Sayısı }\end{array}$ & $\begin{array}{c}\text { Güvenilirlik } \\
\text { Katsayısı }\end{array}$ \\
\hline Duygusal bağlıık & 6 & 0.775 \\
\hline Devam bağlılığı & 6 & 0.705 \\
\hline Normatif bağlııı & 6 & 0.657 \\
\hline Mesleki bağlılık & 18 & 0.805 \\
\hline Denetçi & 21 & 0.680 \\
\hline Denetim firması & 21 & 0.899 \\
\hline Denetimde kalite & 42 & 0.820 \\
\hline
\end{tabular}

Tablo 2 incelendiğinde ankette yer alan değişkenlerden duygusal bağl1l1k boyutunun 0.775 , devam bağl1lığı boyutunun 0.705 , normatif bağlılık boyutunun 
0.657, mesleki bağl1lık boyutunun 0.805 , denetimde kalite alg1 düzeyi boyutlarından denetçi boyutunun 0.680 , denetim firması boyutunun 0.899 , denetimde kalite alg1 düzeyi boyutunun ise 0.820 güvenilirlik katsayısına sahip olduğu görülmektedir.

Farklı bilimciler ve araştırmacılar Alfa $(\alpha)$ değerinin 0,60 ile 0,80 arasında olması durumunda güvenilir kabul edilebileceğini ifade etmişlerdir. Bu aralıkta kabul edilebilir düzeyler: 0,60-0,65 arası istenilir değil (düşük); 0,65-0,70 aras1 asgari düzey (orta); $0,70-0,80$ arası kayda değer (iyi); $0,80-0,90$ arası çok iyi olarak belirtilmiştir (DeVellis, 2017: 109). Bu bağlamda mesleki bağll1ık $(0,805)$ ve denetimde kalite $(0,820)$ boyutlarının katsayılarına bakıldığında kayda değer düzeyde güvenilir olduğu görülmektedir.

Likert tipi ölçek kullanılan anketlerde, veriler normal dağılmaktadır. Normal dağglıma uygunluk Q-Q Plot çizimi ile incelenebilmektedir. Ayrıca, kullanılan verilerin normal dağılım göstermesi çarpıklık ve basıklık değerlerinin \pm 3 arasında olmasına bağlıdır (Seçer, 2017: 30-33). Mesleki bağlılık ve denetimde kalite algısı ölçeklerinin normal dağılım gösterdiği basıklık ve çarpıklık değerleri ($2,86 ; 1,47)$ kontrol edilerek tespit edildiğinden dolayı istatistik değerlendirmelerinde parametrik testler kullanılmıştır. Ancak, normal dağılım göstermeyen veya örnek boyutunun küçük olduğu durumlarda parametrik olmayan analiz teknikleri de kullanılabilmektedir (Coşkun vd., 2017: 2013).

Araştırmada elde edilen veriler SPSS (Statistical Package for Social Sciences) 24.0 programı kullanılarak analiz edilmiştir. Bireylerden toplanan demografik özellikler için tanımlayıcı istatistiklerden olan frekans yüzde değerleri hesaplanarak yorumlanmıştır. Nicel değişkenlerimizin iki ilişkisiz örneklemden elde edilen puanların birbirinden anlamlı bir şekilde farklılık gösterip göstermediğini test etmek için Bağımsız t testi, ilişkisiz iki ya da daha çok örneklem ortalamasının birbirinden anlamlı bir şekilde farklılaşıp farklılaşmadığını test etmek için Tek Yönlü Varyans Analizi (ANOVA) testi uygulanmıştır. Farklılığ1 yaratan grupları tespit etmek için Bonferroni testi yapılmıştır. Tüm testlerde hata oranı belirlenip $\mathrm{p}<0.05$ olduğu durumlarda gruplar arası fark istatistiksel olarak anlamlı kabul edilmiştir.

\subsection{Araştırmanın Hipotezleri}

Çalışmanın amacı doğrultusunda oluşturulan hipotezler;

$\mathrm{H}_{1:}$ Bağımsız denetçinin mesleki bağl1lık düzeyi eğitim seviyesine göre anlamlı farklılık gösterir.

$\mathrm{H}_{2:}$ Bağımsız denetçinin denetimde kalite algı düzeyi eğitim seviyesine göre anlamlı farklılık gösterir. 
$\mathrm{H}_{3:}$ Bağımsız denetçinin mesleki bağl1lık düzeyi mesleki tecrübeye göre anlamlı farklılık gösterir.

$\mathrm{H}_{4}$ : Bağımsız denetçinin denetimde kalite algı düzeyi mesleki tecrübeye göre anlamlı farklılık gösterir şeklindedir.

\section{ARAŞTIRMA BULGULARI}

$\mathrm{Bu}$ bölüm; demografik özelliklere ilişkin tanımlayıcı istatistikler ve hipotezlerin analiz sonuçları ve yorumu alt başlıklarından oluşmaktadır.

\subsection{Demografik Özelliklere İlişkin Tanımlayıcı İstatistikler}

Araştırmaya katılanların demografik özelliklerine ait verilerin dağılımı Tablo 3'te verilmiştir.

Tablo 3. Kişilerin Tanımlayıcı Özelliklerine Göre Dağılımı (n=344)

\begin{tabular}{|c|c|c|c|}
\hline Özellikler & & $\mathbf{n}$ & $\%$ \\
\hline \multirow{2}{*}{ Cinsiyet } & Kadın & 128 & 37.2 \\
\hline & Erkek & 216 & 62.8 \\
\hline \multirow{5}{*}{ Yaş } & $25-28$ & 88 & 25.6 \\
\hline & $29-33$ & 65 & 18.9 \\
\hline & $34-37$ & 85 & 24.7 \\
\hline & $38-41$ & 58 & 16.9 \\
\hline & 42 ve üstü & 48 & 14.0 \\
\hline \multirow{3}{*}{ Ĕ̈itim Seviyesi } & Lisans & 194 & 56.5 \\
\hline & Yüksek Lisans & 143 & 41.5 \\
\hline & Doktora & 7 & 2 \\
\hline \multirow{6}{*}{ Denetçi Ünvanı } & $\begin{array}{l}\text { Sorumlu ortak } \\
\text { baş denetçi }\end{array}$ & 39 & 11.3 \\
\hline & Kıdemli denetçi & 46 & 13.4 \\
\hline & Baş denetçi & 18 & 5.2 \\
\hline & Denetçi & 126 & 36.6 \\
\hline & $\begin{array}{l}\text { Denetçi } \\
\text { yardımcıs1 }\end{array}$ & 101 & 29.4 \\
\hline & Diğer & 14 & 4.1 \\
\hline \multirow{5}{*}{$\begin{array}{l}\text { Meslekte } \\
\text { Süresi }\end{array}$} & $1-5$ & 118 & 34.3 \\
\hline & $6-10$ & 58 & 16.9 \\
\hline & $a_{11-15}$ & 97 & 28.2 \\
\hline & $16-20$ & 41 & 11.9 \\
\hline & 21 yıl üzeri & 30 & 8.7 \\
\hline \multirow{2}{*}{$\begin{array}{l}\text { Firmanızın Faaliyet } \\
\text { Alanı }\end{array}$} & Ulusal & 195 & 56.7 \\
\hline & Uluslararas1 & 149 & 43.3 \\
\hline
\end{tabular}




\begin{tabular}{llcc}
\hline Özellikler & & n & \% \\
\hline \multirow{2}{*}{ Firmanızın Hizmet } & $1-5$ & 134 & 39.0 \\
Süresi & $6-10$ & 25 & 7.3 \\
& $11-15$ & 39 & 11.3 \\
& $16-20$ & 32 & 9.3 \\
Firmanızda KGK & 21 y1l üzeri & 114 & 33.1 \\
Gözetimi & Evet & 262 & 76.2 \\
Firmada Disiplin & Evet & 82 & 23.8 \\
Cezası Uygulama & Hayır & 87 & 25.3 \\
\multicolumn{1}{c}{ Toplam } & & 257 & 74.7 \\
\hline
\end{tabular}

Tablo 3 incelendiğinde araştırmaya katılan denetçilerin \%37,2'sinin kadın, $\% 62,8$ 'inin erkek olduğu görülmektedir. Katılımcıların \%25,6's1 25-28 yaş, \%24,7'si 34-37 yaş, \%18,9'unun 29-33 yaş, \%16,9'u 38-41 yaş ve \%14'ü 42 ve üstü yaş grubundadır.

Kat1lımc1ların \%56,5'sinin lisans mezunu ve \%43,5'inin lisansüstü (yüksek lisans \% 41,5 , doktora \%2) mezunu oldukları tespit edilmiştir. Katılan denetçilerin ünvanlarına baktığımızda \%36,6'sının denetçi, \%29,4'ünün denetçi yardımcısı ve $\% 13,4$ 'ünün kıdemli denetçi oldukları görülmektedir. Araştırmaya katılan bağımsız denetçilerin meslekte çalışma sürelerine bakıldığında ise, \%34,3'ünün 1-5 yıl, \%28,2'sinin 11-15 yıl ve \%16,9'unun 6-10 yıl meslekte çalıştıkları anlaşılmaktadır.

Araştırmaya katılanların \%56,7'sinin ulusal, \%43,3'ünün uluslararası faaliyet gösteren firmalarda çalışma hayatlarına devam ettikleri görülmektedir. Araştırmaya katılan denetçilerin firmalarının \%39'unun 1-5 yıldır, \%33,1'inin 21 yıl ve üzeri ve \%11,3’ünün 11-15 yıldır faaliyetlerini sürdürdükleri tespit edilmiştir.

Katılımcının bağlı bulunduğu firma için gözetimin yapılıp yapılmadığına baktığımızda \% 76,2'sinde yapıldı $\breve{g} 1$, firmada disiplin cezası uygulama durumuna bakıldığında firmaların \%74,7'sinin ceza uygulamadığı tespit edilmiştir. Firmaların sadece $\% 25,3$ 'ünde çalışanlara disiplin cezas1 uygulandığ 1 görülmüştür.

\subsection{Hipotezlerin Analiz Sonuçları ve Yorumu}

Bağımsız denetçinin eğitim seviyesi ve mesleki tecrübesine göre mesleki bağ l1lık ve denetimde kalite algı düzeyinde farklılık olup olmadığını tespit etmek için oluşturulan hipotezler ve analiz sonuçları aşağıda yer almaktadır. 
$H_{1:}$ Bağımsız denetçinin mesleki bağlllık düzeyi eğitim seviyesine göre anlaml farklllık gösterir

Araştırmaya katılanların mesleki bağlılık düzeyi ve alt boyutlarının eğitim seviyesine göre farklılaşıp farklılaşmadığını belirlemek amacıyla bağımsız örneklem t testi uygulanmıştır. Test sonuçları Tablo 4'te verilmiştir.

Tablo 4. Araştırmaya Katılanların Mesleki Bağlılık Düzeyi ve Boyutlarının Eğitim Seviyesine Göre Farklılaşıp Farklılaşmadığını Belirlemek İçin Yapılan t-

Testi Sonuçları

\begin{tabular}{|c|c|c|c|c|}
\hline $\begin{array}{c}\text { Düzeyler ve } \\
\text { Boyutları }\end{array}$ & $\begin{array}{c}\text { Eğitim } \\
\text { Seviyesi }\end{array}$ & $\mathbf{N} \quad \bar{X} \quad$ SS & $\mathbf{t}$ & $\mathbf{p}$ \\
\hline \multirow{2}{*}{$\begin{array}{l}\text { Duygusal } \\
\text { bağlılık }\end{array}$} & Lisans & 1903.970 .69 & \multirow[b]{2}{*}{-2.125} & \multirow[b]{2}{*}{$0.034^{*}$} \\
\hline & $\begin{array}{l}\text { Lisans } \\
\text { üstü }\end{array}$ & 1544.110 .53 & & \\
\hline \multirow{2}{*}{$\begin{array}{l}\text { Devam } \\
\text { bağglılı̆gl }\end{array}$} & Lisans & 1903.470 .72 & \multirow[b]{2}{*}{-2.372} & \multirow[b]{2}{*}{$0.018^{*}$} \\
\hline & $\begin{array}{l}\text { Lisans } \\
\text { üstü }\end{array}$ & 1543.640 .63 & & \\
\hline \multirow{2}{*}{$\begin{array}{l}\text { Normatif } \\
\text { bağlılık }\end{array}$} & Lisans & 1903.260.59 & \multirow[b]{2}{*}{-1.086} & \multirow[b]{2}{*}{0.278} \\
\hline & $\begin{array}{l}\text { Lisan } \\
\text { süstü }\end{array}$ & 1543.330 .63 & & \\
\hline \multirow{2}{*}{$\begin{array}{l}\text { Mesleki } \\
\text { bağlılık }\end{array}$} & Lisans & 1903.570 .50 & \multirow[b]{2}{*}{-2.500} & \multirow[b]{2}{*}{$0.013^{*}$} \\
\hline & $\begin{array}{l}\text { Lisans } \\
\text { üstü }\end{array}$ & 1543.690 .45 & & \\
\hline
\end{tabular}

Tablo 4'de yer alan analiz sonuçları incelendiğinde, katılımcıların eğitim seviyesine göre mesleki bağl1lık düzeyi boyutlarından duygusal bağl1lı ve devam bağlılığı alt boyutlarında istatistiksel açıdan anlamlı bir farklılık görüldügüü tespit edilmiştir $(\mathrm{p}<0.05)$. Buna göre; lisans üstü eğitim alanların duygusal bağl1lık ve devam bağlılığının lisans eğitimi alanlara göre daha yüksek olduğu görülmektedir. Ancak, katılımcıların eğitim seviyesine göre mesleki bağl1lık düzeyi boyutlarından normatif bağl1lık alt boyutunun ise, istatistiksel açıdan anlamlı bir farkl11lk göstermediği tespit edilmiştir ( $>00.05)$. Araştırmaya katılanların eğitim seviyesine göre mesleki bağlılık düzeyi boyutuna bakıldığında ise; yapılan t testi sonuçlarına göre, istatistiksel açıdan anlamlı bir farklılık gösterdiği tespit edilmiştir $(\mathrm{p}<0.05)$.

$H_{2:}$ Bă̆ımsız denetçinin denetimde kalite algı düzeyi ĕgitim seviyesine göre anlamlı farklılık gösterir 
Araştırmaya katılanların denetimde kalite algı düzeyi ve boyutlarının eğitim seviyesine göre farklılaşıp farklılaşmadığını belirlemek amacıyla bağımsız örneklem $t$ testi uygulanmıştır. Test sonuçları Tablo 5'te verilmiştir.

Tablo 5. Araştırmaya Katılanların Denetimde Kalite Algı Düzeyi ve Boyutlarının Eğitim Seviyesine Göre Farklılaşıp Farklılaşmadığını Belirlemek İçin Yapılan t-Testi Sonuçları

\begin{tabular}{clccccc}
\hline $\begin{array}{c}\text { Düzeyler ve } \\
\text { Boyutları }\end{array}$ & \multicolumn{1}{c}{$\begin{array}{c}\text { Eğitim } \\
\text { Seviyesi }\end{array}$} & N & $\bar{X}$ & SS & t & p \\
\hline Denetçi & Lisans & 190 & 3.80 & 0.29 & - \\
& Lisansüstü & 154 & 3.87 & 0.24 & $2.391^{0.017^{*}}$ \\
\hline \multicolumn{2}{c}{ Denetim } & Lisans & 190 & 4.02 & 0.52 & - \\
firması & Lisansüstü & 154 & 4.13 & 0.46 & $2.087^{0.038^{*}}$ \\
\multicolumn{2}{c}{ DenetimdeLisans } & 190 & 3.91 & 0.32 & - \\
kalite & Lisansüstü & 154 & 4.00 & 0.28 & $2.745^{0.006 *}$ \\
${ }^{*} \mathrm{p}<0.05 ;$ & & & & &
\end{tabular}

Tablo 5 incelendiğinde katılımcıların eğitim seviyesine göre denetimde kalite alg1 düzeyi boyutlarından denetçi ve denetim firması alt boyutunun istatistiksel açıdan anlamlı bir farklılık gösterdiği tespit edilmiştir $(\mathrm{p}<0.05)$. Bu sonuçlara göre; lisans üstü eğitim alanların denetçi ve denetim firması alt boyutunda denetimde kalite algisının lisans eğitimi alanlara göre daha yüksek olduğu görülmektedir. Yapılan bu test sonuçları, araştırmaya katılanların eğitim seviyesine göre denetimde kalite algı düzeyinin istatistiksel açıdan anlamlı bir farklılık gösterdiğini ortaya koymaktadır $(\mathrm{p}<0.05)$.

$H_{3:}$ Bağımsız denetçinin mesleki bă̆lllık düzeyi mesleki tecrübeye göre anlamlı farklılık gösterir

Araştırmaya katılanların mesleki bağlılık düzeyi ve boyutlarının meslekteki çalışma süresine göre farklılaşıp farklılaşmadığını belirlemek amacıyla $F$ testi yapılmıştır. Test sonuçları Tablo 6'da verilmiştir.

Tablo 6. Araştırmaya Katılanların Mesleki Bağl11ık Düzeyi ve Boyutlarının Meslekteki Çalışma Süresine Göre Farklılaşıp Farklılaşmadığını Belirlemek İçin Yapılan Varyans Analizi Sonuçları

\begin{tabular}{lllllllr}
\hline $\begin{array}{c}\text { Düzeyler ve } \\
\text { Boyutları }\end{array}$ & $\begin{array}{c}\text { Meslekteki } \\
\text { Çalışma Süresi }\end{array}$ & N & $\bar{X}$ & SS & F & p & Bonferroni \\
\hline Duygusal & $1-5(1)$ & 118 & 4.05 & 0.59 & $5.5670 .000 *$ & $1>2$ \\
bağlılık & $6-10(2)$ & 58 & 3.74 & 0.74 & & $2<3,2<4$ \\
& $11-15(3)$ & 97 & 4.15 & 0.54 & &
\end{tabular}




\begin{tabular}{|c|c|c|c|c|}
\hline & \multirow{2}{*}{$\begin{array}{l}16-20(4) \\
21 \text { y1l ve üzeri } \\
\text { (5) }\end{array}$} & \multicolumn{3}{|c|}{$41 \quad 4.23 \quad 0.58$} \\
\hline & & 30 & 3.910 .68 & \\
\hline \multirow{5}{*}{$\begin{array}{l}\text { Devam } \\
\text { bağlılığı }\end{array}$} & $1-5(1)$ & 118 & $3.340 .675 .8430 .000^{*}$ & $1<3,1<5$ \\
\hline & $6-10(2)$ & 58 & 3.450 .85 & \\
\hline & $11-15(3)$ & 97 & 3.710 .57 & \\
\hline & $16-20(4)$ & 41 & 3.660 .56 & \\
\hline & 21 y1l ve üzeri (5) & 30 & 3.780 .63 & \\
\hline \multirow{5}{*}{$\begin{array}{l}\text { Normatif } \\
\text { bağlılık }\end{array}$} & $1-5(1)$ & 118 & 3.210 .561 .8390 .121 & \\
\hline & $6-10(2)$ & 58 & 3.200 .58 & \\
\hline & $11-15(3)$ & 97 & 3.340 .68 & \\
\hline & $16-20(4)$ & 41 & 3.450 .54 & \\
\hline & 21 y1l ve üzeri (5) & 30 & 3.390 .59 & \\
\hline \multirow{5}{*}{$\begin{array}{l}\text { Mesleki } \\
\text { bağlılık }\end{array}$} & $1-5(1)$ & 118 & $3.540 .445 .2820 .000^{*}$ & $1<3,1<4$ \\
\hline & $6-10(2)$ & 58 & 3.470 .56 & $2<3,2<4$ \\
\hline & $11-15(3)$ & 97 & 3.730 .49 & \\
\hline & $16-20(4)$ & 41 & 3.780 .38 & \\
\hline & 21 y1l ve üzeri (5) & 30 & 3.690 .41 & \\
\hline
\end{tabular}

Tablo 6'da yer alan varyans analizi (F testi) sonuçları incelendiğinde, katılımcıların meslekteki çalışma süresine göre mesleki bağl1lık düzeyi alt boyutlarından duygusal bağlllık boyutunun istatistiksel açıdan anlamlı bir farklılık gösterdiği tespit edilmiştir $(\mathrm{p}<0.05)$. Tabloda $16-20$ yıl çalışma süresine sahip olan grubun duygusal bağl1lık düzeyinin diğer gruplardan daha yüksek olduğu görülmektedir. Katılımcıların meslekteki çalışma süresine göre mesleki bağl1lık düzeyi alt boyutlarından devam bağlllı̆̆ boyutuna bakıldığında ise istatistiksel açıdan anlamlı bir farklılık gösterdiği tespit edilmiştir $(\mathrm{p}<0.05)$. Tabloda 21 yıl ve üzeri çalışma süresine sahip olan grubun devam bağl1lığının diğer gruplardan yüksek olduğu görülmektedir. Sonuçlara normatif bağlllık boyutunda bakıldığında ise istatistiksel açıdan anlamlı bir farklılık göstermediği tespit edilmiştir ( $>0.05)$. Tabloda gösterilen sonuçlara mesleki bağlllık üst boyutunda bakıldığında katılımcıların meslekteki çalışma süresine göre mesleki bağl1lık düzeyinin istatistiksel açıdan anlamlı bir farklılık gösterdiği görülmektedir $(\mathrm{p}<0.05)$.

$\mathrm{Bu}$ sonuçlara göre; meslekte çalışma süresi 16-20 y1l olan katılımcıların duygusal bağll1ık düzeyi, mesleki çalışma süresi 21 yıl ve üzeri olan katılımcıların devam bağlılığ düzeyi, meslekte çalışma süresi 1-5 yıl olanlara göre daha yüksek olduğu tespit edilmiştir. Bu durumda tabloda verilen sonuçlara göre meslekte çalışma süresi arttıkça duygusal ve devam bağlılık düzeyinin de artacağı söylenebilir. 
$H_{4:}$ Bağımsız denetçinin denetimde kalite algı düzeyi mesleki tecrübeye göre anlamll farklıllk gösterir

Araştırmaya katılanların denetimde kalite alg1 düzeyi ve boyutlarının meslekteki çalışma süresine göre farklılaşıp farklılaşmadığını belirlemek amacıyla $\mathrm{F}$ testi yapılmıştır.

Tablo 7. Araştırmaya Katılanların Denetimde Kalite Algı Düzeyi ve Boyutlarının Meslekteki çalışma süresine Göre Farklılaşıp Farklılaşmadığını Belirlemek İçin Yapılan Varyans Analizi Sonuçları

\begin{tabular}{|c|c|c|c|c|c|c|c|}
\hline $\begin{array}{c}\text { Düzeyler ve } \\
\text { Boyutları }\end{array}$ & $\begin{array}{c}\text { Meslekteki } \\
\text { Çalışma } \\
\text { Süresi }\end{array}$ & $\mathbf{N}$ & $\bar{X}$ & SS & $\mathbf{F}$ & $\mathbf{p}$ & Bonferroni \\
\hline \multirow{5}{*}{ Denetçi } & $1-5(1)$ & 118 & 3.84 & 0.48 & \multirow{5}{*}{\multicolumn{2}{|c|}{1.7820 .132}} & \\
\hline & $6-10$ (2) & 58 & 3.84 & 0.23 & & & \\
\hline & $11-15$ (3) & 97 & 3.81 & 0.25 & & & \\
\hline & $16-20(4)$ & 41 & 3.92 & 0.33 & & & \\
\hline & $\begin{array}{l}21 \text { y1l ve } \\
\text { üzeri (5) }\end{array}$ & 30 & 3.76 & 0.33 & & & \\
\hline \multirow{5}{*}{$\begin{array}{l}\text { Denetim } \\
\text { firması }\end{array}$} & $1-5(1)$ & 118 & 3.96 & 0.50 & \multirow{5}{*}{\multicolumn{2}{|c|}{ 7.1870.000* }} & $1<3,1<4$ \\
\hline & $6-10(2)$ & 58 & 3.89 & 0.63 & & & $2<3,2<4$ \\
\hline & $11-15$ (3) & 97 & 4.21 & 0.38 & & & \\
\hline & $16-20(4)$ & 41 & 4.23 & 0.36 & & & \\
\hline & $\begin{array}{l}21 \text { y1l ve } \\
\text { üzeri (5) }\end{array}$ & 30 & 4.16 & 0.45 & & & \\
\hline \multirow{5}{*}{$\begin{array}{l}\text { Denetimde } \\
\text { kalite }\end{array}$} & $1-5(1)$ & 118 & 3.90 & 0.32 & \multirow{5}{*}{\multicolumn{2}{|c|}{ 4.8810.001* }} & $1<4$ \\
\hline & 6-10 (2) & 58 & 3.86 & 0.35 & & & $2<3,2<4$ \\
\hline & $11-15$ (3) & 97 & 4.01 & 0.23 & & & \\
\hline & $16-20(4)$ & 41 & 4.08 & 0.30 & & & \\
\hline & $\begin{array}{l}21 \text { y1l ve } \\
\text { üzeri (5) }\end{array}$ & 30 & 3.96 & 0.34 & & & \\
\hline
\end{tabular}

Tablo 7'de yer alan F testi sonuçları incelendiğinde katılımcıların meslekteki çalışma süresine göre denetimde kalite algısı düzeyi boyutlarından denetçi boyutunun istatistiksel açıdan anlamlı bir farklılık göstermediği tespit edilmiştir (p>0.05). Ancak, denetimde kalite düzeyi boyutlarından denetim firmas1 boyutunun istatistiksel açıdan anlamlı bir farklılık gösterdiği tespit edilmiştir $(p<0.05)$. Sonuçlara bakıldığında, 16-20 yıl çalışma süresine sahip olan grubun denetimde kalite algısının diğer gruplardan (1-5, 6-10, 11-15 y1l) yüksek olduğu görülmektedir. Bu durumda, denetçinin tecrübesi arttıkça denetimde kalite alg1 düzeyinin artacağ 1 söylenebilir. 


\section{SONUÇ}

Bağımsız denetimin kaliteli bir şekilde yürütülmesinde birçok unsurun etkisi bulunmaktadır. $\mathrm{Bu}$ unsurlardan ikisi bağımsız denetçinin mesleki tecrübesi ile eğitim seviyesidir. $\mathrm{Bu}$ iki unsur denetim faaliyetinin kaliteli bir şekilde yürütülmesinin yanında mesleki bağlılı̆̆ın artmasında da etkindirler. Eğitim mesleki bilginin güncellenmesine etki ederek denetçilerin her anlamda meydana gelebilecek değişikliklere ve mesleki gelişmelere hazırlıklı olmasını sağlayacaktır.

Bağımsız denetçinin eğitim seviyesi ve mesleki tecrübesine göre mesleki bağl1lık ve denetimde kalite algı düzeyinde anlamlı bir farklılık olup olmadığının incelendiği bu araştırma sonucunda, denetçilerin mesleki bağlllık ve denetimde kalite alg1 düzeyinin eğitim seviyesine göre istatistiksel açıdan anlamlı bir farklılık gösterdiği; lisans üstü eğitim alan denetçilerin mesleki bağlılık ve denetimde kalite alg1 düzeyinin, lisans eğitim alan denetçilere göre daha yüksek olduğu tespit edilmiştir.

Ayrıca araştırmada bağımsız denetçilerin mesleki bağl1lık ve denetimde kalite algı düzeyinin mesleki tecrübeye göre istatistiksel açıdan anlamlı bir farklılık gösterdiği tespit edilmiştir. Bu farklılık, meslekte çalışma süresi 16-20 yıl olan denetçilerin mesleki bağlılık ve denetimde kalite algı düzeyinin diğer gruplardan daha yüksek olduğu şeklindedir. Bu sonuçlara göre; denetçilerin mesleki tecrübesi ve eğitim düzeyleri yükseldikçe mesleki bağl1lık düzeyleri ve denetimde kalite algı düzeylerinin artacağı söylenebilir. Bu bağlamda, denetçiler lisansüstü eğim almaları konusunda teşvik edilebilir.

\section{KAYNAKÇA}

Akçay, Aysel, Bilen, Abdulkadir (2019), "Denetim Kalitesinde Kâr Yönetimi Üzerine Etkisi: Bist-100 Firmaları Üzerine Bir Uygulama", Muhasebe ve Finansman Dergisi, S. 83, ss. 25-44.

Al-Thuneibat, Ali - Abedagqader, Issa, - Ream Tawfiq Ibrahim Al, Baker, - Rana Ahad Ata (2011), "Do audit tenure and firm size contribute to audit quality? Empirical evidence from Jordan”, Managerial Auditing Journal, 26(4), ss. 317-334.

Aslanoğlu, Suphi ve Başkan, Tuba Derya (2016), "Denetçilerin Bağımsızlığının Denetim Kalitesine Etkisi: BİST' de Bir Uygulama”, Muhasebe ve Denetime Bakış, S. 48, ss. 59-84.

Aslanoğlu, Suphi - Cengiz, Selim - Dinç, Yusuf - Dilsiz, Şükrü (2016), "Yaratıcı Muhasebe Uygulamalarının Bağımsız Denetim Kalitesi Üzerine 
Etkisi: BíST’ de Bir Uygulama”, Muhasebe ve Finans Dergisi, Say1 69, ss.1-24.

Bakan, İsmail (2011), Örgütsel Bağlıık, Gazi Kitabevi, Ankara

Blau, Gary (2003), “Testing for a four-dimensional structure of occupational commitment", Journal Of Occupational And Organizational Psychology, 76(4), ss. 469-488.

Coşkun, Recai- Altunışık, Remzi - Yıldırım, Engin (2017), Sosyal Bilimlerde Araştırma Yöntemleri SPSS Uygulamalı (9. Baskı). Sakarya Yayınc1lk, Sakarya.

Cahan, Seteven F. ve Sun, Jerry (2015), "The Effect Of Audit Experience On Audit Fees And Audit Quality”, Journal of Accounting, Auditing \& Finance, 30(1), ss. 78-100.

Çetin, Mehmet, - Cihangiroğlu, Necmettin, - Türk, Yusuf Ziya (2010), "Bir Grup Eczacının Mesleki Bağlılık Algılarının İncelenmesi”, Pamukkale Tıp Dergisi, 3(3), ss. 125-130.

DeAngelo, Linda Elizabeth (1981), “Auditor Size And Audit Quality”, Journal Of Accounting And Economics, 3(3), pp. 183-199.

DeVellis, Rober F. (2017), Ölçek Geliştirme Kuram ve Uygulamaları, (Çev. Totan, Tarık) (3. Baskı), Nobel Yayınları, Ankara

Davidson, Ronald A. ve Neu, Dean (1993), "A note on the association between audit firm size and audit quality”, Contemporary Accounting Research, 9(2), ss. 479-488.

Erdoğan, Nurten ve Azgın, Nurcan (2019), "Denetçilerin Denetim Kalitesine İlişsin Teorik Algıları ve Pratikteki Uygulamalarının Karşılaştırılması", Muhasebe ve Denetime Bakış, 18(56), ss. 49-62.

Esen, Fevzi M. ve Timor, Mehpare (2019), “Çok Değişkenli Aykırı Değer Tespiti İçin Klasik ve Dayanıklı Mahalanobis Uzaklık Ölçükleri: Finansal Veri ile Bir Uygulama", Uluslararası İktisadi ve İdari İncelemeler Dergisi, S. 25, ss. 267-282.

Gör, Yusuf (2016), "Kurumsal Yönetim Uygulamalarının Denetim Kalitesine Etkisi: Bağımsız Denetim Şirketleri Üzerine Bir Araştırma”, Doktora Tezi, Süleyman Demirel Üniversitesi Sosyal Bilimler Enstitüsü, Isparta 
Koca, Nurettin (2019), Bağımsız Denetçinin Mesleki Bağlılığı ve Denetimde Kalite Algısı, Gazi Kitabevi, Ankara

Lee, Kibeom - Carswell, Julie J - Allen, Natalie J. (2000), “A Meta-Analytic Review Of Occupational Commitment: Relations With Person-And Work-Related Variables”, Journal of Applied Psychology, 85(5), pp. 799-811.

Lennox, Clive S. - Wu, Xi - Zhang, Tianyu (2014), "Does Mandatory Rotation Of Audit Partners Improve Audit Quality?", The Accounting Review, 89(5), ss. 1775-1803.

Mgbame, C. O - Izedonmi, F. I. O. - Enofe, A. (2012), “Gender Factor In Audit Quality: Evidence From Nigeria”, Reserach Journal of Finance and Accounting, 3(4), ss. 81-88.

Meyer, John P. - Allen, Natalie. J. - Smith, Catherine A. (1993), “Commitment To Organizations And Occupations: Extension And Test Of A Three-Component Conceptualization”, Journal of Applied Psychology, 78(4), ss. 538-551.

Mills, Maura J. ve Fullagar, Clive J. (2017), "Engagement Within Occupational Trainees: Individual Difference Predictors And Commitment Outcome”, Journal of Vocational Behavior, 98, pp. 3545.

Nakip, Mahir (2006), Pazarlama Araştırmaları Teknikler ve (SPSS Destekli) Uygulamalar, Seçkin Yayıncılık, Ankara,

Seçer, İsmail (2017), SPSS ve LISREL ile Pratik Veri Analizi Analiz ve Raporlaştırma, Anı Yayınları, Ankara

Selimoğlu, Seval Kardeş ve Yeşilçelebi, Gül (2014), "Mesleki Aidiyetin Bağımsız Denetim Kalitesi Üzerine Etkisi: Bağımsız Denetçiler Üzerine Bir Araştırma", Muhasebe ve Finansman Dergisi, S. 64, ss. 2752.

Özdevecioğlu, Mahmut ve Aktaş, Aylin (2007), “Kariyer Bağlılığı, Mesleki Bağlılığın ve Örgütsel Bağlılığın Yaşam Tatmini Üzerinde Etkisi: İşAile Çatışmasının Rolü”, Erciyes Üniversitesi İktisadi ve İdari Bilimler Fakültesi Dergisi, 28 (Ocak-Haziran), ss. 1-20.

Özmen, Ömür Timurcanday - Özer, Pınar Süral - Saatçioğlu, Ömur Yaşar (2005), “Akademisyenlerde Örgütsel ve Mesleki Bağlılığın İncelenmesine 
İlişkin Bir Örnek Araştırma”, Dokuz Eylül Üniversitesi İşletme Fakültesi Dergisi, 6(2), ss. 1-14.

Tak, Birçin ve Çiftçioğlu, B. Aydem (2008), "Mesleki Bağlılık ile Çalışanların Örgütte Kalma Niyeti Arasındaki İlişkiyi İncelemeye Yönelik Görgül Bir Çalışma”, Ankara Üniversitesi Siyasal Bilgiler Fakültesi Dergisi, 63(4), ss. 155-178.

Tak, Bilçin ve Çiftçioğlu, B. Aydem (2009), "Üç Boyutlu Mesleki Bağlılık Ölçeğinin Türkçe 'de Güvenilirlik ve Geçerliliğinin İncelenmesine Yönelik Bir Alan Araştırması”, DÜ İşletme Fakültesi Dergisi, 10(1), ss. 35-54.

Yaşar, Alpaslan (2013), “Bağımsız Dış Denetim Kuruluşlarına Yönelik Gözetim ve Denetim Etkinliğinin Bağımsız Dış Denetim Kalitesi ile İlişkisi: Türkiye Değerlendirmesi”, Ç.Ü. Sosyal Bilimler Enstitüsü Dergisi, 22(1), ss. 465-480.

http://www.kgk.gov.tr/DynamicContentDetail/5223/Bağımsı-Denetçi-ResmiSicili, (16.10.2017).

http://www.kgk.gov.tr/DynamicContentDetail/5217/Bağımsı-DenetimKuruluşu-Resmi-Sicili, (16.10.2017) 